\title{
IMPLEMENTASI PERLINDUNGAN HUKUM TERHADAP PEREMPUAN KORBAN KEKERASAN DALAM RUMAH TANGGA DI KOTA MADIUN
}

\author{
Nuswantari ${ }^{1}$ \\ Universitas PGRI Madiun ${ }^{1}$ \\ Email: nusinuswantari@gmail.com ${ }^{1}$ \\ Naskah diterima: 30/08/2017 revisi: 20/09/2017 disetujui: 26/10/2017
}

\begin{abstract}
Abstrak
Penelitian ini bertujuan untuk mengetahui: apakah implementasi perlindungan hukum terhadap perempuan korban KDRT di kota Madiun sudah sesuai dengan UU No.23 Th 2004. Penelitian ini merupakan penelitian hukum non-doktrinal dengan pendekatan interaksional mikro dan memakai metode kualitatif. Analisis data dilakukan dengan teknik analisis kualitatif dengan metode analisis interaktif. Kesimpulan penelitian ini adalah: Implementasi perlindungan hukum terhadap perempuan korban KDRT di Kota Madiun belum sesuai dengan Undang-Undang No. 23 Tahun 2004. Hambatan yang dihadapi adalah: belum adanya petunjuk teknis pelaksanaan perempuan korban KDRT, perundang-undangan yang lain belum merefleksikan keadilan bagi perempuan, aparat hukum masih bias gender, kultur hukum masyarakat masih bias gender dan patriarkhis. Langkah-langkah yang sudah ditempuh adalah: mengadakan komunikasi dan koordinasi yang efektif antar penegak hukum, meningkatkan sikap dan integritas yang tinggi para aparat penegak hukum dalam menjalankan tugas dan fungsinya, dan mensosialisasikan kepada seluruh masyarakat tentang keberadaan UndangUndang Nomor 23 Tahun 2004.
\end{abstract}

Kata kunci: Implementasi; Perlindungan Hukum; Perempuan Korban KDRT

\section{IMPLEMENTATION OF LEGAL PROTECTION ON WOMAN VICTIMS OF HARDNESS IN HOUSEHOLD IN MADIUN CITY}

\begin{abstract}
The aims of the research are: to find out how the legal protection toward women as the victims of harassment within household is implemented based on the Law Number 23 the Year of 2004. This is a non-doctrinal legal study with a micro interaction approach and a qualitative method. The data were analyzed by using a qualitative analysis technique with an interactive analysis. The conclusions of this research are: the legal protection toward women as the victims of harassment within household have not completely implemented based on the Law Number 23 the Year of 2004. The constraints they face are : there have not been any practical guidelines in implementing the legal protection toward women as the victims of harassment within household, the legal contents of the existing laws have not reflected justice for women, the structure of laws or law agencies is gender-biased, and the legal culture of community is still gender-biased and patriarchic. The measures taken to overcome the constraints are: conducting communication and coordination effectively among the legal upholders, improving attitude and integrity quality of the legal upholders in executing their duties and functions, and socializing and disseminating the Law Number 23, the Year of 2004 on elimination of harassment within Household to the community.
\end{abstract}

Keywords: The Implementation, Legal Protection, Woman as the Victims of Harassment within Household. 


\section{PENDAHULUAN}

Undang-Undang Nomor 23 tahun 2004 tentang Penghapusan Kekerasan Dalam Rumah Tangga (PKDRT) memberikan perlindungan secara khusus bagi korban kekerasan yang terjadi dalam lingkup rumah tangga, dan dilaksanakan berdasarkan azas penghormatan hak asasi manusia, keadilan dan kesetaraan gender, non diskriminasi dan perlindungan korban, serta mempunyai tujuan untuk mencegah segala bentuk kekerasan dalam rumah tangga, melindungi korban dan menindak pelaku kekerasan dalam rumah tangga serta memelihara keutuhan rumah tangga yang harmonis dan sejahtera. Keberadaan undang-undang ini diharapkan dapat memberikan perlindungan hukum bagi anggota dalam rumah tangga, khususnya perempuan yang paling banyak menjadi korban kekerasan dalam rumah tangga.

Penelitian ini memfokuskan pada salah satu bentuk kekerasan yang seringkali diabaikan, tetapi justru yang paling banyak dialami oleh perempuan, yaitu kekerasan dalam rumah tangga (domestic-violence) yang terjadi di Kota Madiun. Kurang diperhatikannya masalah kekerasan yang terjadi dalam rumah tangga, lebih banyak disebabkan tempatnya di wilayah domestik, namun justru masalah dan kasus kekerasan dalam rumah tangga inilah yang mengalami peningkatan. Diperkirakan banyak kasus kekerasan dalam rumah tangga di Kota Madiun yang menimpa perempuan tidak pernah terungkap secara terbuka, hal ini mungkin terjadi karena perempuan yang terkena kasus malu dan takut untuk melaporkannya, sehingga tidak dapat diungkapkan. Tetapi apabila semua perempuan jujur dan memiliki keberanian untuk melaporkan tindakan kekerasan dalam rumah tangga yang dialami atau yang terjadi di sekitarnya, niscaya angka yang terekspose akan jauh lebih besar.

Dengan memperhatikan semakin meningkatnya korban dan kasus tindak kekerasan yang menimpa kaum perempuan di Kota Madiun maka persoalan tersebut menjadi persoalan dan gejala patologi sosial serius yang perlu segera ditangani, dicarikan jalan pemecahannya dan diantisipasi agar tidak terus berkembang. Berdasarkan pada paparan latar belakang masalah tersebut, peneliti tertarik untuk mengetahui tentang pelaksanaan perlindungan hukum terhadap perempuan korban kekerasan dalam rumah tangga di Kota Madiun periode tahun 20162017.

Dengan melihat permasalahan yang ada di lapangan, maka permasalahan dalam penelitian ini dapat dirumuskan: 1). Apakah implementasi perlindungan hukum terhadap perempuan korban kekerasan dalam rumah tangga di Kota Madiun pada tahun 20162017 sudah sesuai dengan UndangUndang Nomor 23 Tahun 2004 ? 2). Hambatan-hambatan apakah yang dihadapi? 3). Langkah-langkah apakah yang sudah dilaksanakan untuk mengatasi hambatanhambatan tersebut ? 4). Solusi alternatif apakah yang dapat diajukan kepada Pemerintah Kota Madiun dan Penegak Hukum Kota Madiun untuk dapat mengimplementasikan perlindungan hukum terhadap perempuan korban kekerasan dalam rumah tangga di Kota Madiun?

Tujuan pokok penelitian ini adalah untuk: 1) mengetahui apakah implementasi perlindungan hukum terhadap perempuan korban kekerasan dalam rumah tangga di Kota Madiun pada tahun 2016-2017 sudah sesuai dengan Undang-Undang Nomor 23 Tahun 2004? 2) mengetahui hambatan - hambatan apakah yang dihadapi? 3) mengetahui langkah-langkah apakah yang sudah dilaksanakan untuk mengatasi hambatan-hambatan tersebut? mengetahui solusi alternatif apakah yang dapat diajukan kepada Pemerintah Kota Madiun dan Penegak Hukum Kota Madiun untuk dapat mengimplementasikan perlindungan hukum terhadap perempuan korban kekerasan dalam rumah tangga di Kota Madiun yang sesuai dengan UndangUndang Nomor 23 Tahun 2004.

Implementasi Kebijaksanaan Hukum

Nuswantari, Implementasi Perlindungan....| 98 
Menurut Udoji (1981 : 32) sebagaimana yang dikutip oleh Solichin Abdul Wahab (2004 : 59) dengan tegas mengatakan bahwa " the execution of appolicies is as important if not more important than policy-making. Policies will remain dreams or blue prints file jackets unless they are implemented", maksudnya bahwa pelaksanaan kebijaksanaan adalah sesuatu yang penting, bahkan mungkin jauh lebih penting daripada pembuatan kebijaksanaan. Beberapa kebijaksanaan akan sekedar berupa impian atau rencana bagus yang tersimpan rapi dalam arsip apabila tidak diiplementasikan.

Lebih lanjut menurut Daniel A. Mazmanian dan Paul A. Sabatier (1979) dalam Solichin Abdul Wahab (2004 : 65), menjelaskan bahwa makna implementasi adalah :

"Memahami apa yang senyatanya terjadi sesudah suatu program dinyatakan berlaku atau dirumuskan merupakan fokus perhatian implementasi kebijaksanaan, yakni kejadian-kejadian dan kegiatan-kegiatan yang timbul sesudah disahkannya pedomanpedoman kebijaksanaan negara, yang mencakup baik usaha-usaha untuk mengadministrasikannya maupun untuk menimbulkan akibat atau dampak nyata pada masyarakat atau kejadian-kejadian”.

Berdasarkan pandangan yang disampaikan oleh kedua ahli tersebut dapat disimpulkan bahwa proses implementasi kebijaksanaan itu sesungguhnya tidak hanya menyangkut perilaku badan-badan administratif yang bertanggung jawab untuk melaksanakan program dan menimbulkan ketaatan pada diri kelompok sasaran, melainkan juga menyangkut jaringan kekuatan-kekuatan politik, ekonomi dan sosial yang langsung atau tidak langsung dapat mempengaruhi perilaku dari semua pihak yang terlibat, dan yang pada akhirnya berpengaruh terhadap dampak baik yang diharapkan (intended) maupun yang tidak diharapkan (spillover/negative effects).

\section{Kekerasan Dalam Rumah Tangga}

Berdasarkan

Undang-Undang

Nomor 23 tahun 2004 Pasal 1 ayat (1) yang dimaksudkan dengan kekerasan dalam rumah tangga adalah setiap perbuatan terhadap seseorang terutama perempuan, yang berakibat timbulnya kesengsaraan atau penderitaan secara fisik, seksual, psikologis, dan atau penelantaran rumah tangga termasuk ancaman untuk melakukan perbuatan, pemaksaan, atau perampasan kemerdekaan secara melawan hukum dalam lingkup rumah tangga.

\section{Perlindungan Hukum Terhadap Perempuan Korban Kekerasan Dalam Rumah Tangga}

2004 Undang-Undang Nomor 23 Tahun Dalam Rumah Tangga, menegaskan bahwa korban kekerasan dalam rumah tangga berhak mendapatkan perlindungan dari pihak keluarga, kepolisian, kejaksaan, pengadilan, advokat, lembaga sosial atau pihak lain baik sementara maupun berdasarkan penetapan perintah perlindungan dari pengadilan (Pasal 10 huruf (a)). Selain itu korban juga berhak memperoleh pelayanan kesehatan sesuai dengan kebutuhan medis (Pasal 10 huruf (b); penanganan secara khusus berkaitan dengan kerahasiaan korban (Pasal 10 huruf (c)); pendampingan oleh pekerja sosial dan bantuan hukum, pada setiap tingkat proses pemeriksaan sesuai dengan ketentuan peraturan perundang-undangan (Pasal 10 huruf (d)) dan pelayanan bimbingan rohani (Pasal 10 huruf (e)). Pemerintah mempunyai kewajiban dan tanggung jawab dalam upaya pencegahan kekerasan dalam rumah tangga (Pasal 11). Masyarakat berkewajiban melakukan upaya sesuai batas kemampuannya untuk mencegah berlangsungnya tindak pidana, memberikan perlindungan kepada korban, memberikan pertolongan darurat dan membantu proses pengajuan permohonan penetapan perlindungan (Pasal 15).

Peran aparat penegak hukum dalam mengimplementasikan perlindungan hukum terhadap perempuan korban kekerasan dalam rumah tangga berdasarkan Undangundang Nomor 23 Tahun 2004 : (1). Peran 
Kepolisian: diatur pasal 16 sampai dengan Pasal 20, Pasal 26, Pasal 27, Pasal 35 dan Pasal 36. (2). Peran Kejaksaan : diatur pasal 10 huruf (a). (3). Peran Advokat : diatur Pasal 25 Huruf (a), (b) dan (c). (4) Peran Pengadilan : diatur pasal 28 sampai dengan Pasal 34, Pasal 37 dan Pasal 38. Aparat penegak hukum, yaitu : kepolisian, kejaksaan, advokat dan pengadilan, dalam memberikan perlindungan terhadap korban kekerasan dalam rumah tangga dapat bekerjasama dengan tenaga kesehatan, pekerja sosial, relawan, pendamping dan pembimbing rohani (Pasal 21 sampai dengan pasal 24).

\section{Hukum Sebagai Suatu Sistem Norma.}

Berbagai pengertian tentang hukum, sebagai suatu sistem, dikemukakan antara lain oleh Lawrence Friedman dalam Esmi Warassih (2005 : 30), bahwa hukum itu merupakan gabungan komponen struktur, substansi dan kultur :

Pertama Komponen struktur, yaitu kelembagaan yang diciptakan oleh sistem hukum itu dengan berbagai macam fungsi dalam rangka mendukung bekerjanya sistem tersebut. Komponen ini dimungkinkan untuk melihat bagaimana sistem hukum itu memberikan pelayanan terhadap penggarapan bahan-bahan hukum secara teratur.

Kedua Komponen substansi, yaitu sebagai output dari sistem hukum, berupa peraturan-peraturan, keputusan-keputusan yang digunakan baik oleh pihak yang mengatur maupun yang diatur.

Ketiga Komponen kultur, yaitu terdiri dari nilai-nilai dan sikap-sikap yang mempengaruhi bekerjanya hukum atau oleh Lawrence M. Friedman disebut sebagai kultur hukum. Kultur hukum inilah yang berfungsi sebagai jembatan yang menghubungkan antara peraturan hukum dengan tingkah laku hukum, hal ini hendaknya dibedakan antara internal legal culture yaitu kultur hukum para lawyers and judges, dan external legal culture yaitu kultur hukum masyarakat luas".

\section{METODE}

\section{Jenis Penelitian}

Penelitian ini termasuk jenis penelitian Hukum Non Doktrinal atau penelitian Hukum Sosiologis. Sedangkan apabila dilihat dari sifatnya termasuk penelitian Deskriptif Kualitatif. Pendekatan yang dipakai adalah pendekatan Interaksional Mikro, dengan analisis kualitatif. Apabila dilihat dari bentuknya, maka penelitian ini termasuk ke dalam bentuk penelitian evaluatif . Lokasi penelitian di wilayah Kota Madiun.

\section{Waktu dan Tempat Penelitian}

Penelitian ini dilaksanakan pada bulan agustus 2016 sampai dengan bulan juli 2017. Tempat penelitian di lingkungan Pemerintah kota Madiun,yaitu di Dinas Keluarga Berencana Kependudukan dan Catatan Sipil Bidang Pemberdayaan Perempuan, Instansi Kepolisian Resort Kota Madiun,Instansi Kejaksaan Kota Madiun, Instansi Pengadilan Negeri Kota Madiun dan Instansi Pengadilan Agama Kota Madiun.

\section{Target/Subjek Penelitian}

Tehnik sampling dalam penelitian ini dilakukan secara snow ball sampling, dimana peneliti melakukan pemilihan elemen sampel sambil berjalan, sampai diperoleh jumlah elemen sampel yang memenuhi syarat (J. Supranto, 2003: 35). Dengan tehnik sampling ini ditentukan subyek penelitian sebagai berikut: Aparat Dinas Keluarga Berencana Kependudukan dan Catatan Sipil bidang Pemberdayaan Perempuan Kota Madiun, dan Aparat Penegak Hukum kota Madiun( Kepolisian Resort, Kejaksaan Negeri, Pengadilan Negeri, Pengadilan Agama) yang pernah ataupun yang sedang menangani kasus KDRT dan subyek pendukung 7(tujuh) orang perempuan korban KDRT yang kasusnya sedang menjalani proses persidangan ataupun yang sudah menjalani putusan Pengadilan Negeri Kota Madiun. 
Jenis data dalam penelitian ini adalah: Data Primer, yaitu data yang diperoleh secara langsung dari lapangan dan Data Sekunder, yaitu keterangan-keterangan atau pengetahuan yang secara tidak langsung diperoleh melalui studi kepustakaan, bahanbahan dokumenter, tulisan ilmiah dan hasil penelitian lain.

Sumber Data dalam penelitian ini adalah sumber data primer: Sumber data ini didapatkan secara langsung dari lapangan atau masyarakat sebagai subyek penelitian, peristiwa, tingkah laku yang didapat melalui wawancara yang mendalam (indepth interview), dan Sumber Data Sekunder: meliputi bahan hukum primer, bahan hukum sekunder dan bahan hukum tersier.

Teknik sampling dalam penelitian ini dilakukan secara snow ball sampling. Subyek penelitian dalam penelitian ini adalah aparat Dinas Keluarga Berencana, Kependudukan dan Catatan Sipil bidang Pemberdayaan Perempuan Kota Madiun serta aparat Penegak Hukum Kota Madiun (Kepolisian Resort, Kejaksaan Negeri, Pengadilan Negeri), yang pernah ataupun yang sedang menangani kasus kekerasan dalam rumah tangga, ataupun yang sudah menjalani putusan Pengadilan Negeri Kota Madiun.

\section{Data, Intrumen, dan Teknik Pengumpulan Data}

Pengumpulan data dalam penelitian ini dengan teknik wawancara, observasi langsung dan studi dokumen. Sedangkan pemilihan rancangan analisis data dalam penelitian ini menggunakan analisis kualitatif dengan pola berfikir deduktif dan induktif secara kombinasi, yang didasarkan pada tiga komponen utama yaitu: Reduksi data(data reduction), Penyajian data(data display), dan

kesimpulan(verification).

\section{Teknik Analisis Data}

Proses analisis data dilakukan dengan menggunakan model analisis mengalir(flow model of analysis), artinya melakukan analisis dengan menjalin secara paralel ketiga komponen analisis secara terpadu, (baik sebelum mengumpulkan ata, pada saat mengumpulkan data dan sesudah mengumpulkan data. Aktivitas ketiga komponen analisis itu berbentuk interaksi dengan proses pengumpulan data sebagai proses siklus. Model analisis data penelitian ini dapat digambarkan pada gambar 1 sebagai berikut:

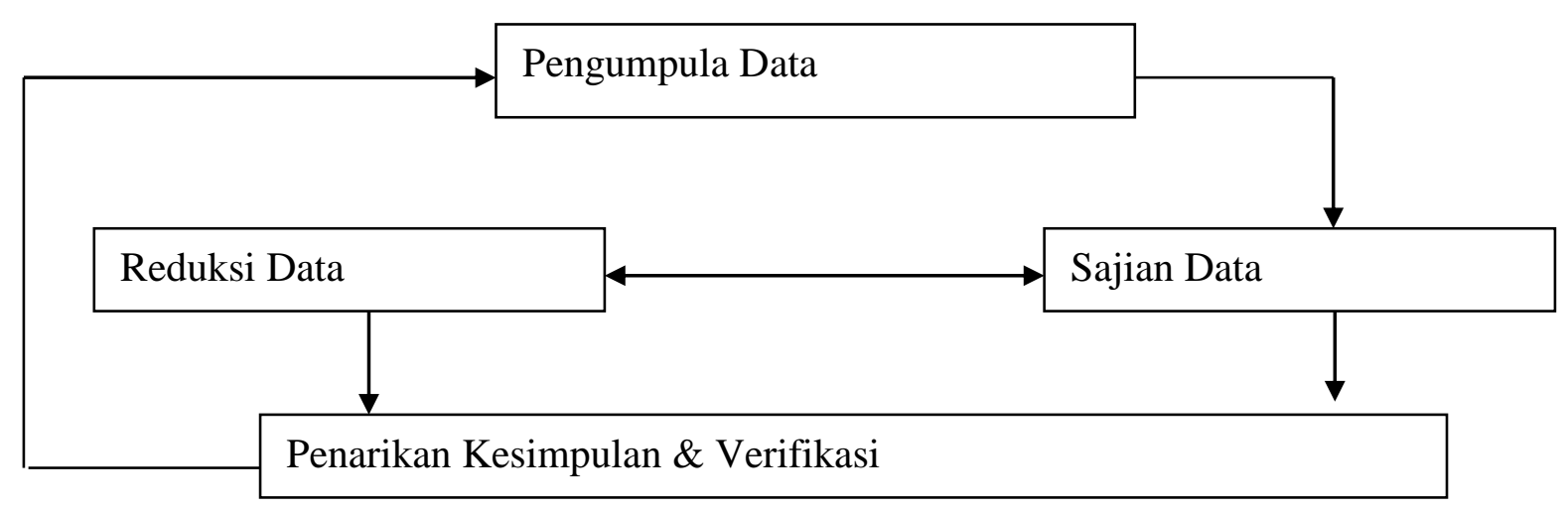

Gambar 1. Model analisis data

dan perempuan yang menjadi korban kekerasan dalam rumah tangga, yang kasusnya sedang dalam proses persidangan

\section{HASIL DAN PEMBAHASAN}

Implementasi Perlindungan Hukum Terhadap Perempuan Korban Kekerasan 
Dalam Rumah Tangga, Hambatan-hambatan yang di hadapi dan langkah-langkah yang sudah dilaksanakan oleh Pemerintah Kota Madiun dan Penegak Hukum Kota Madiun:

\section{Oleh Pemerintah Kota Madiun.}

Sudah diadakan sosialisasi tentang perlindungan dan kesetaraan jender, dengan sasaran organisasi wanita, tokoh masyarakat, dinas instansi terkait, kecamatan-kecamatan, kelurahan-kelurahan dan PKK Kota Madiun. Hambatan yang dihadapi adalah belum adanya alokasi dana yang jelas untuk mewujudkan perlindungan hukum terhadap perempuan korban kekerasan dalam rumah tangga. Langkahlangkah yang sudah dilaksanakan adalah secara berkala mengadakan sosialisasi kepada masyarakat dan merencanakan pembentukan Pusat Pelayanan Terpadu Perlindungan Perempuan Dan Anak (P2T P2A) di wilayah Kota Madiun.

Oleh Kepolisian Resort Kota Madiun.

Pelaksanaan tugas Kepolisian dalam memberikan perlindungan hukum terhadap perempuan korban kekerasan dalam rumah tangga dilaksanakan oleh tim Ruang Pelayanan Khusus (RPK), yang beranggotakan polisi wanita. Ruang Pelayanan KhususRPK) di dalam menjalankan tugas menempuh tahap-tahap sebagai berikut :Pre-emptif, Preventif dan Represif.

Data tentang bentuk bentuk kasus KDRT yang diperoleh dari Ruang Pelayanan Khusus (RPK) Polresta Madiun ,bulan Agustus 2016 sampai dengan bulan Juli 2017 dapat dilihat pada tabel 1, dan data tentang latar belakang pekerjaan dan tingkat ekonomi keluarga korban dan pelaku KDRT di kota Madiun pada bulan Agustus 2016 sampai dengan bulan Juli 2017 dapat dilihat pada tabel 2, selanjutnya data tentang usia dan latar belakang pendidikan korban dan palaku kasus KDRT di kota Madiun pada bulan Agustus 2016 sampai dengan bulan Juli 2017 disajikan pada tabel 3, sebagai berikut :

Tabel 1 : Data Bentuk Kasus Kekerasan Dalam Rumah Tangga di Kota Madiun Tahun 2016 2017

\begin{tabular}{|c|c|c|c|c|c|c|c|}
\hline \multirow[t]{3}{*}{ No } & \multirow[t]{3}{*}{ Bentuk Kasus } & \multicolumn{6}{|c|}{ Jumlah Kasus } \\
\hline & & \multirow[t]{2}{*}{2016} & \multirow[t]{2}{*}{2017} & \multicolumn{2}{|c|}{2016} & \multicolumn{2}{|c|}{2017} \\
\hline & & & & dicabut & diputus & dicabut & Diputus \\
\hline \multirow[t]{3}{*}{1} & Fisik: & & & & & & \\
\hline & Penganiayaan berat & 1 & 1 & & 1 & & 1 \\
\hline & Penganiayaan ringan & & 4 & & & 3 & 1 \\
\hline \multirow[t]{5}{*}{2} & Psikologis: & & & & & & \\
\hline & Dikatai Kotor & & & & & & \\
\hline & Ingkar Janji & & & & & & \\
\hline & Didiamkan & & & & & & \\
\hline & Diselingkuhi & & 1 & & & & 1 \\
\hline \multirow[t]{2}{*}{3} & Ekonomi: & & & & & & \\
\hline & Tidak Dinafkahi & & 1 & & & & 1 \\
\hline \multirow[t]{3}{*}{4} & Seksual: & & & & & & \\
\hline & Perkosaan & & & & & & \\
\hline & Pelecehan Seksual & & & & & & \\
\hline & Jumlah & 1 & 7 & & 1 & 3 & 4 \\
\hline
\end{tabular}


Citizenship Jurnal Pancasila dan Kewarganegaraan Vol 5 No 2 Oktober 2017, hal 12-22 Avaliable online at : http://e-journal.unipma.ac.id/index.php/Citizenship

ISSN: 2302-433X (print) 2579-5740 (online)

Tabel 2 : Data Latar Belakang Pekerjaan dan Tingkat Ekonomi Korban Dan Pelaku Kasus Kekerasan Dalam Rumah Tangga Tahun 2016-2017.

\begin{tabular}{|c|c|c|c|c|c|c|c|c|c|c|c|c|}
\hline \multirow[t]{3}{*}{ No } & \multicolumn{6}{|c|}{ Pekerjaan } & \multicolumn{6}{|c|}{ Tingkat Ekonomi } \\
\hline & \multicolumn{3}{|c|}{ Korban } & \multicolumn{3}{|c|}{ Pelaku } & \multicolumn{3}{|c|}{2016} & \multicolumn{3}{|c|}{2017} \\
\hline & $\mathrm{Tb}$ & $\mathrm{Sw}$ & Pn & $\mathrm{Tb}$ & $\mathrm{Sw}$ & $\mathrm{Pn}$ & $\mathrm{Bw}$ & Th & At & $\mathrm{Bw}$ & Th & At \\
\hline 1 & & $\sqrt{ }$ & & & $\sqrt{ }$ & & & $\sqrt{ }$ & & & & \\
\hline 2 & $\sqrt{ }$ & & & & $\sqrt{ }$ & & & & & & $\sqrt{ }$ & \\
\hline 3 & & $\sqrt{ }$ & & & $\sqrt{ }$ & & & & & & & $\sqrt{ }$ \\
\hline 4 & $\sqrt{ }$ & & & & $\sqrt{ }$ & & & & & & $\sqrt{ }$ & \\
\hline 5 & $\sqrt{ }$ & & & & & $\sqrt{ }$ & & & & & $\sqrt{ }$ & \\
\hline 6 & $\sqrt{ }$ & & & & $\sqrt{ }$ & & & & & & $\sqrt{ }$ & \\
\hline 7 & $\sqrt{ }$ & & & & $\sqrt{ }$ & & & & & & $\sqrt{ }$ & \\
\hline 8 & $\sqrt{ }$ & & & $\sqrt{ }$ & & & & & & & $\sqrt{ }$ & \\
\hline & & & $\mathrm{mla}$ & & & & & 1 & & & 6 & 1 \\
\hline
\end{tabular}

Sumber : POLRESTA Madiun Tahun 2016-2017

Keterangan : $\mathrm{Tb}=$ Tidak bekerja, $\mathrm{Sw}=$ Swasta $/$ wiraswasta/bakulan, $\mathrm{PN}=$ Pegawai Negeri Sipil, Bw = Ekonomi Bawah, Th = Ekonomi Tengah, At = Ekonomi Atas

Tabel 3 : Data Usia Dan Latar Belakang Pendidikan Korban Dan Pelaku Kasus Kekerasan Dalam Rumah Tangga Tahun 2016-2017.

\begin{tabular}{|c|c|c|c|c|c|c|c|c|c|c|}
\hline \multirow[t]{3}{*}{ No } & \multicolumn{4}{|c|}{ Tahun Usia } & \multicolumn{6}{|c|}{ Pendidikan } \\
\hline & \multicolumn{2}{|c|}{ Korban } & \multicolumn{2}{|c|}{ Pelaku } & \multicolumn{3}{|c|}{ Korban } & \multicolumn{3}{|c|}{ Pelaku } \\
\hline & 2016 & 2017 & 2016 & 2017 & SLTP & SLTA & PT & SLTP & SLTA & PT \\
\hline 1 & 42 & & 45 & & $\sqrt{ }$ & & & & $\sqrt{ }$ & \\
\hline 2 & & 50 & & 51 & $\sqrt{ }$ & & & $\sqrt{ }$ & & \\
\hline 3 & & 35 & & 37 & & $\sqrt{ }$ & & & $\sqrt{ }$ & \\
\hline 4 & & 20 & & 26 & & $\sqrt{ }$ & & & $\sqrt{ }$ & \\
\hline 5 & & 35 & & 53 & & $\sqrt{ }$ & & & $\sqrt{ }$ & \\
\hline 6 & & 19 & & 23 & & $\sqrt{ }$ & & & $\sqrt{ }$ & \\
\hline 7 & & 34 & & 31 & & $\sqrt{ }$ & & & $\sqrt{ }$ & \\
\hline 8 & & 21 & & 18 & $\sqrt{ }$ & & & $\sqrt{ }$ & & \\
\hline & & Jumla & & & 3 & 5 & & 2 & 6 & \\
\hline
\end{tabular}

Sumber : POLRESTA Madiun Tahun 2016-2017

Hambatan yang dihadapi Polresta Kota Madiun adalah tidak adanya dukungan struktural dari POLRI, belum tersedianya shelter (rumah aman) dan pencabutan kasus kekerasan oleh korban atas kemauan sendiri, hal ini disebabkan karena korban merasa malu baik secara psikologis maupun sosiologis, korban tidak punya keyakinan kasusnya memperoleh keadilan. 


\section{Citizenship Jurnal Pancasila dan Kewarganegaraan Vol 5 No 2 Oktober 2o17, hal 97-107 Avaliable online at : http://e-journal.unipma.ac.id/index.php/Citizenship ISSN: 2302-433X (print) 2579-5740 (online)}

Langkah-langkah yang sudah dilaksanakan untuk mengatasi hambatanhambatan tersebut adalah tim RPK menggunakan uang pribadi untuk membantu korban menjalani pemeriksaan medis. Sehubungan belum tersedianya shelter, RPK menitipkan korban kekerasan dalam rumah tangga kepada keluarganya atau saudaranya dengan mendapatkan pantauan keamanan dari pihak Kepolisian dan memberikan dukungan moril kepada korban serta memberi penjelasan bahwa kekerasan dalam rumah tangga merupakan pelanggaran terhadap martabat manusia.

\section{Kejaksaan Negeri Kota Madiun}

Kepala Kejaksaan Negeri Kota Madiun sudah menunjuk jaksa perempuan untuk menangani kasus kekerasan dalam rumah tangga dan menangani perkara kekerasan dalam rumah tangga dengan proses penanganan perkara kategori penting (PK - Ting). Langkah-langkah yang sudah dilaksanakan adalah dalam melaksanakan tugasnya Jaksa Penuntut Umum sering memberikan nasehat kepada korban di luar persidangan dan sudah melakukan koordinasi dengan aparat penegak hukum lain.

\section{Pengadilan Negeri Kota Madiun}

Majelis Hakim di dalam persidangan memperkenankan hadirnya pedamping korban. Hambatan yang dihadapi adalah adanya pencabutan kembali kasus kekerasan dalam rumah tangga oleh korban disebabkan korban merasa malu, takut dan tidak menginginkan suaminya dihukum berat, cukup diberi peringatan agar jera melakukan tindak kekerasan terhadap isteri. Langkah-langkah yang sudah dilaksanakan untuk mengatasi hambatanhambatan tersebut adalah pihak Pengadilan Negeri sudah melakukan koordinasi dan kerjasama dengan penegak hukum yang lain, serta memberikan dukungan moril kepada korban.

Walaupun upaya untuk melakukan penghapusan kekerasan dalam rumah tangga serta sosialisasi isu kekerasan dalam rumah tangga merupakan pelanggaran hak asasi terhadap perempuan semakin gencar dilakukan oleh Pemerintah Kota Madiun dan Penegak Hukum Kota Madiun, namun perubahan ke arah perbaikan hak-hak perempuan dan penegakan hak-hak perempuan berjalan lambat. Memang harus diakui bahwa hingga saat ini Pemerintah Kota Madiun dan Penegak Hukum Kota Madiun belum dapat mengimplementasikan perlindungan hukum terhadap perempuan korban kekerasan dalam rumah tangga sesuai undang-undang yang berlaku, karena adanya beberapa hambatan dalam penegakannya. Namun kiranya langkahlangkah yang sudah dilaksanakan sudah mencerminkan semangat Undang-Undang Nomor 23 Tahun. 2004.

Hambatan-hambatan yang dihadapi oleh Pemerintah Kota Madiun dan Penegak Hukum Kota Madiun adalah : adanya substansi hukum lain atau peraturan perundangan-undangan yang tidak memihak pada perempuan korban kekerasan dalam rumah tangga, yaitu KUHP, KUHAP, Undang-Undang Nomor 1 Tahun 1974 tentang Perkawinan, yang menempatkan perempuan tidak sederajat dengan laki-laki (istri adalah ibu rumah tangga dan suami adalah kepala rumah tangga). Keberadaan substansi hukum demikian ini, sangat mempengaruhi cara pandang aparat penegak hukum dalam menafsirkan hukum yang akan ditegakkan, akibatnya masih ada beberapa aparat penegak hukum yang bias jender dalam melaksanakan UndangUndang Nomor 23 Tahun 2004.

Kultur hukum atau budaya hukum masyarakat Kota Madiun yang bias jender dan patriarkhi, yaitu sikap atau perilaku masyarakat yang belum mengakomodir dan peka terhadap persoalan kekerasan dalam rumah tangga.. Budaya patriarkhi mengakibatkan laki-laki merasa lebih superior dari perempuan, sehingga laki-laki dibenarkan menguasai perempuan. Stigma negatif diberikan kepada istri yang berani melawan suami. Istri harus selalu menjaga 
keharmonisan rumah tangga dan mengalah pada suami untuk menjaga dampak buruk kepada anak-anak.

Langkah-langkah yang sudah ditempuh oleh Pemerintah Kota Madiun dan Penegak Hukum Kota Madiun untuk mengatasi hambatan-hambatan yang muncul adalah mengadakan komunikasi dan koordinasi yang efektif antar penegak hukum, meningkatkan sikap dan integritas yang tinggi para aparat penegak hukum dalam menjalankan tugas dan fungsinya dan mensosialisasikan kepada seluruh masyarakat tentang keberadaan UndangUndang Nomor 23 Tahun 2004.

Solusi alternatif yang dapat diajukan kepada pemerintah kota madiun dan penegak hukum kota madiun untuk dapat mengimplementasikan perlindungan hukum terhadap perempuan korban kekerasan dalam rumah tangga di kota Madiun yaitu segera mewujudkan Sistem Peradilan Pidana Terpadu Yang Berkeadilan Jender Dalam Penanganan Kasus Kekerasan Terhadap Perempuan (SPPT-PKKTP), sistem peradilan pidana ini merupakan sistem terpadu yang menunjukkan proses keterkaitan antara instansi atau pihak yang berwenang menangani kasus kekerasan terhadap perempuan dalam rumah tangga dan akses pelayanan yang mudah serta terjangkau bagi perempuan dalam setiap proses peradilan kasus kekerasan terhadap perempuan dalam rumah tangga.

\section{SIMPULAN DAN SARAN}

\section{Simpulan}

Berdasarkan hasil analisis dan pembahasan dapat disimpulkan bahwa implementasi perlindungan hukum terhadap perempuan korban kekerasan dalam rumah tangga di Kota Madiun belum sesuai dengan Ketentuan Undang-Undang No. 23 Tahun 2004 . Hambatan-hambatan yang dihadapi adalah: 1. adanya perundang-undangan lain yang belum merefleksikan keadilan bagi perempuan 2. sikap aparat hukum masih bias jender 3. kultur hukum masyarakat masih bias jender dan patriakhi. Langkahlangkah yang sudah ditempuh untuk mengatasi hambatan-hambatan tersebut adalah: sudah mengadakan komunikasi dan koordinasi yang efektif antar penegak hukum, meningkatkan sikap dan integritas yang tinggi aparat penegak hukum dalam menjalankan tugas dan fungsinya, dan mensosialisasikan kepada seluruh masyarakat mengenai Undang-Undang Nomor 23 Tahun 2004. Solusi alternatif yang dapat diajukan untuk dapat mengimplementasikan perlindungan hukum adalah dengan segera mewujudkan sistem peradilan pidana terpadu yang berkeadilan jender dalam penanganan kasus kekerasan dalam rumah tangga..

\section{Saran}

Bedasarkan pembahasan dan hasil temuan maka saran yang dapat disampaikan pada penelitian ini yakni

Kepada Pemerintah Pusat untuk dapat mengalokasikan dana dari kas negara untuk meningkatkan kuantitas dan kualitas lembaga-lembaga pemberi layanan bagi perempuan korban kekerasan dalam rumah tangga.

Kepada Pemerintah Kota Madiun : Dapat mengalokasikan dana dari APBD untuk mewujudkan lembaga pelayanan hukum terhadap perempuan korban kekerasan dalam rumah tangga. Perlu kiranya mendekonstruksikan kembali ideologi patriarkhi yang sedemikian kuat menguasai mindset masyarakat.

Kepada Aparat Penegak Hukum Kota Madiun: Perlu adanya surat keputusan bersama instansi penegak hukum tentang koordinasi penanganan kasus kekerasan dalam rumah tangga.

Kepada Masyarakat Kota Madiun, yang respect terhadap persoalan-persoalan 
perempuan : Untuk membantu penanganan perempuan korban kekerasan dalam rumah tangga, maka perlu diadakan shelter-shelter yang diadakan oleh lembaga-lembaga yang concern terhadap persoalan-persoalan perempuan. Peran serta aktif masyarakat dalam merespon dan melaporkan kasus kekerasan dalam rumah tangga dilingkungannya kepada kepolisian.

\section{DAFTAR PUSTAKA}

Cholil, A. (1996). Tindak Kekerasan Terhadap Wanita. Yogyakarta.

Endang Sumiarni, M. (2005, February 2). Kekerasan Terhadap Perempuan Dalam Perspektif Undang-Undang Penghapusan Kekerasan Dalam Rumah Tangga. Makalah. Disampaikan Pada Loka Karya Persiapan Kompetisi Peradilan Semu (Moot Court) Wilayah Jawa Tengah Dan Yogyakarta. Yogyakarta.

Hamim, A. (2001). Menjadi Suami Sensitif Gender. Yogyakarta: Rifka Annisa Womens Crisis Center.

Harkrisnowo, H. (2000). Hukum Pidana Dan Kekerasan Terhadap Perempuan. Bandung: Alumni.

Hukum, T. P. (2005, April). Sistem Peradilan Pidana Terpadu Yang Berkeadilan Gender Dalam Penanganan Kasus Kekerasan Terhadap Perempuan. Jakarta : Komnas Perempuan - LBH APIK Jakarta - LBPP DERAP - Warapsari - Convention Watch - PKWJ UI dan European Commission.

Irianto, S. (2005, February 2). Feminist Legal Theory (Pendekatan Hukum Berspektif Perempuan. . Makalah. Disampaikan Pada Loka Karya Persiapan Kompetisi Peradilan Semu (Moot Court) Wilayah Jawa Tengah Dan Yogyakarta. Yogyakarta.

Irsan, K. (n.d.). Peran Polisi dalam Perlindungan Hukum Bagi Wanita.
Makalah Disampaikan Pada Lokakarya "Hak Perempuan dan Peran Penegak Hukum. Yogyakarta: Kerja sama FH UGM, Kejaksaan Agung RI dan Kelompok Kerja Convention Watch, Program Studi Kajian Wanita Program Pasca Sarjana Universitas Indonesia.

Luhulima, A. S. (2000). Pemahaman Bentuk-bentuk Tindak Kekerasan Terhadap Perempuan dan Alternatif Pemecahannya. Jakarta: PT. Alumni

Natalie Kollimann, E. (1998). Kekerasan Terhadap Perempuan. Jakarta: Yayasan Lembaga Konsumen Indonesia.

Nunuk P. Murniati, A. (2004). Getar Gender Perempuan Indonesia dalam perspektif Agama, Budaya dan Keluarga. Magelang : Indonesia Siatera.

Perempuan, K. (2005, March 8). Lokus Kekerasan Terhadap Perempuan 2004 : Rumah, Pekarangan dan Kebun. Catatan tahunan tentang Kekerasan Terhadap Perempuan 2005. Jakarta: Komnas Perempuan.

Sjurkie, E. S. (2001). Peran Hakim dalam Perlindungan Hukum Bagi Wanita. Yogyakarta: Makalah Disampaikan Pada Lokakarya " Hak Perempuan dan Peran Penegak Hukum : Kerja sama FH UGM, Kejaksaan Agung RI dan Kelompok Kerja Convention Watch, Program Studi Kajian Wanita Program Pasca Sarjana Universitas Indonesia.

Soekanto, S. (2004). Penelitian Hukum Kualitatif. Jakarta: UI Press.

Sulistyowati I, Achie Sudiarti Luhulima. (2004). Kisah Perjalanan Panjang Konvensi Wanita di Indonesia. . Jakarta: Yayasan obor Indonesia anggota IKAPI DKI Jakarta.

Sumarno. (2001, October 25). Penerapan Hukum Tentang Perlindungan Hakhak Perempuan Dalam Perspektif 
Citizenship Jurnal Pancasila dan Kewarganegaraan Vol 5 No 2 Oktober 2017, hal 12-22 Avaliable online at : http://e-journal.unipma.ac.id/index.php/Citizenship ISSN: $2302-433 \mathrm{X}$ (print) 2579-5740 (online)

Jaksa. . Yogyakarta: Makalah Disampaikan Pada Lokakarya " Hak Perempuan dan Peran Penegak Hukum : Kerja sama FH UGM, Kejaksaan Agung RI dan Kelompok Kerja Convention Watch, Program Studi Kajian Wanita Program Pasca Sarjana Universitas Indonesia.

Tapi Omas Ihromi, Sulistyowati Irianto, Achie Sudiarti Luhulima. (2000). Penghapusan Diskriminasi Terhadap Wanita. Bandung: Alumni.
Wahab, S. A. (2004). Analisis Kebijaksanaan Dari Formulasi Ke Implementasi Kebijaksanaan Negara. Jakarta: PT Bumi Aksara.

Warassih, E. (2005). Pranata Hukum Sebuah Telaah Sosiologis. Semarang: Suryandaru Utama.

Undang-Undang Rebublik Indonesia Nomor 23 Tahun 2004. Tentang Penghapusan Kekerasan Dalam Rumah Tangga. 